\section{REFERENCES AND NOTES}

1. Acharya, P. T., and Payne, W. W.: Blood chemistry of normal full-term infants in the first 48 hours of life. Arch. Dis. Childhood, 40: 430 (1965)

2. Albert, M. S., and Winters, R. W.: Acid-base equilibrium of blood in normal infants. Pediatrics, 37: 728 (1966).

3. Cassady, G.: Bromide space studies in infants of low birth weight. Pediat. Res., 4 14 (1970).

4. Cassady, G., and Milstead, R. R.: Antipyrine space studies and cell water estimates in infants of low birth weight. Pediat. Res., 5: 673 (197!).

5. Cotlove, E.: Determination of chloride in biological materials. In: D. Glick: Methods of Biochemical Analysis, Vol. XII, p. 277 (Interscience Publishers, John Wiley \& Sons, New York, 1964).

6. Dahl, L. K.: Salt and hypertension. Amer. J. Clin. Nutr., 25: 231 (1972).

7. Day, G. M., Chance, G. W., Radde, I C., Reilly, B. J., Park, E., and Sheepers, J.: Growth and mineral metabolism in very low birth weight infants. II. Effects of calcium supplementation on growth and divalent cations. Pediat. Res., 9. 568 (1975).

8. Day, G. M Radde, I. C., Balfe, J. W., and Chance, G. W.: Electrolyte abnormalities in very low birth weight (VLBW) infants. Pediat. Res., 10:522 (1976).

9. Dubowitz, L. M. S., Dubowitz, V., and Goldberg, C.: Clinical assessment of gestational age in the newborn infant. J. Pediat., 77: 1 (1970)

10. Hill, D . E and Hancock, R. G. V. The measurement of extracellular fluid volume by neutron activation of bromide. Slowpoke Nuclear Reactor at the University of Toronto, Annual Report, August 1974

11. Honour, J. W., Shackleton, C. H. L., and Valman, H. B.: Sodium homeostasis in preterm infants. Lancet, ii: 1147 (1974).

12. Macy, I. G., Kelly, H. J., and Sloan, R. E.: The composition of milks: A compilation of the comparative composition and properties of human, cow, and goat milk, colostrum, and transitional milk. (Publication No. 254, National Academy of Sciences-National Research Council, Washington, D.C., 1953)

13. McIntosh, N., Shaw, J. C. L., and Taghizadeh, A.: Direct evidence for calcium and trace mineral deficits in the skeleton of preterm infants. Pediat. Res., 8:896 (1974).

14. Mendelsohn, D., and Levin, N. W.: A colorimetric micromethod for the estimation of antipyrine in plasma or serum. S. Afr. J. Med. Sci., 25: 13 (1960).

15. Metcoff, J.: Synchrony of organ development contributing to water and electrolyte regulation in early life. Clin. Nephrol., 1: 107 (1973).

16. Nash, M. A., and Edelmann, C. M. Jr.: The developing kidney. Immature function or inappropriate standard? Nephron, 11:71 (1973)
17. O'Donnell, A. M., Ziegler, E. E., and Fomon, S. J.: Ingestas recomendadas de nutrientes para prematuros en crecimiento. Arch. Argent. Pediat., 72: 126 (1974).

18. Sharman, G. B.: Adaptation of marsupial pouch young for extrauterine existence. In: C. R. Austin: Mammalian Fetus in Vitro, p. 67 (Chapman \& Hall, London, 1973).

19. Shaw, J. C. L.: Parenteral nutrition in the management of sick low birth weight infants. Pediat. Clin. N. Amer., 20: 333 (1973).

20. Shaw J. C. L. Malnutrition in premature infants. Proc. Nutr. Soc., 33: 103 (1974)

21. Steichen, J. J., and Kleinman, L. I.: Influence of dietary sodium intake on rena maturation in unanesthetized canine puppies. Proc. Soc. Exp. Biol. Med., 148. 748 (1975)

22. Sulyok, E. The relationship between electrolyte and acid-base balance in the premature infant during early postnatal life. Biol. Neonate, 17: 227 (1971).

23. Widdowson, E. M.: The fetus and neonate. In: N. S. Assali: Biology of Gestation Vol. II, p. 19 (Academic Press, New York, 1968).

24. Willis, D. M Roy, N R Chance, G W Ackerman, I, Park, E., and Radde, C.: Growth of very low birth weight (VLBW) infants: Effects of acidosis, caloric intake and hyponatremia. Pediat. Res., 8:452 (1974).

25. Air Shields (Canada), Ltd., 22 Lepage Court, Downsview, Ontario.

26. SMA-S26, Wyeth Ltd., 4455 Chesswood Drive, P. O. Box 10, Downsview, 461, Ontario.

27. Ampicillin, $200 \mathrm{mg} / \mathrm{kg} / 24 \mathrm{hr}$ iv, supplying $0.66 \mathrm{mEq} / \mathrm{kg} / 24 \mathrm{hr}$ of $\mathrm{Na}^{+}$. Gentamicin, $3 \mathrm{mg} / \mathrm{kg} / 24 \mathrm{hr} i m$, supplying $0.02 \mathrm{mEq} / \mathrm{kg} / 24 \mathrm{hr}$ of $\mathrm{Na}^{+}$.

28. We are particularly grateful to Miss A. Zitman, R.N., and Miss A. Turner, R.N., for their assistance in conducting and supervising specimen collections and body size measurements; to the nursing staff of the Neonatology Unit and the staff of the Formula Room. Hospital for Sick Children, for their help and interest in the study. We also wish to acknowledge the collaboration of the Medical Staff, Hospital for Sick Children, in permitting their patients to be studied. We thank Mr. J. Fabenyi, R.T., B.Agr., for skilful technical assistance. We are grateful to Dr. J. Silverio and Wyeth Ltd. for their generous supply of formula used.

29. This study was supported in part by the Medical Research Council, Canada (Grant MA 4635).

30. Requests for reprints should be addressed to: I. C. Radde, M.D., Research Institute, The Hospital for Sick Children, 555 University Ave., Toronto, Ontario M5G 1 X8 (Canada)

31. Accepted for publication December 18, 1975
Cystic fibrosis fibroblasts polyamines spermidine spermine

\title{
The Effect of Spermidine and Spermine on Proliferation in Vitro of Fibroblasts from Normal and Cystic Fibrosis Patients
}

\author{
WILLIAM A. GAHL, JAMES E. CHANGUS, AND HENRY C. PITOT ${ }^{143}$
}

Departments of Oncology and Pathology, University of Wisconsin School of Medicine, Madison, Wisconsin, USA

\section{Extract}

The effects of spermidine and spermine at varying concentrations upon the replicative ability of human fibroblasts in cell culture have been studied. The average concentrations of spermidine causing a $50 \%$ inhibition of proliferation $\left(I_{50}\right)$ after 3 days of growth for three normal cell strains and three strains derived from patients with cystic fibrosis ( CF) were $4.4 \times 10^{-6} \pm 1.2 \mathrm{M}$ and $6.2 \times 10^{-6} \pm 2.1$ $M$, respectively. The values for spermine were $2.0 \times 10^{-6} \pm 0.5 \mathrm{M}$ for normal and $2.2 \times 10^{-6} \pm 0.1 \mathrm{M}$ for fibroblasts from cystic fibrosis patients. No significant difference between the replicative ability of normal and CF cell strains was seen over a wide range of polyamine concentrations employed for a period of up to 3 days.

\section{Speculation}

This work shows no difference in the replicative ability of fibroblasts obtained from normal or CF patients when exposed to spermidine or spermine. We cannot relate the results of this study to recent reports of increased blood cell polyamine levels in cystic fibrosis, but examination of cellular uptake and metabolism of polyamines may allow us to do so in the future. 
The aliphatic polyamines, spermidine and spermine, as well as their metabolic precursor, 1,4-diaminobutane (putrescine), have been recognized for their growth-stimulating properties $(9,16,32$, 36). However, polyamines have been shown to exhibit cytotoxic effects, specifically upon the tubercle bacillus (19), bacteria (31), and cultured eukaryotic cells including KB cells (17), hamster fibroblasts and mouse embryo cells (26), Ehrlich ascites cells (6), P-1534 and L-1210 mammalian cells (4), and Walker carcinosarcoma cells (13). These studies, along with others which correlate polyamine content with cellular proliferative activity $(11,20,33)$, suggest a significant role for polyamines in growth regulation.

Polyamines may be of etiologic significance in CF. This recessive pediatric disease presents with abnormally viscous glandular secretions causing variable amounts of obstruction and damage to organs such as the pancreas, lungs, liver, and salivary glands. The increased sweat salinity of CF individuals provides a major diagnostic criterion (12). These and other clinical observations have suggested that the fundamental physiologic defect of the disorder is associated with abnormalities in the process of secretion by exocrine glands (22). Unfortunately, the basic molecular defect remains unknown. However, the membrane-active nature of polyamines $(16,24)$, along with their resemblance to the so-called CF factors (5), has spurred interest in a possible relation of polyamines to CF. Recent reports of abnormal polyamine levels in CF patients (30) suggest an altered metabolism for polyamines in this disease. If this is true, fibroblasts from CF patients may exhibit a reduced ability to tolerate the addition of exogenous polyamines to their growth media in vitro. Whether or not the $C F$ fibroblast in culture manifests a differential toxicity of polyamines compared with normal cell strains is the question to which this study addresses itself.

\section{MATERIALS AND METHODS}

Fetal calf serum, nutrient media F-12, trypsin, and penicillin/ streptomycin were obtained from Gibco (37) and spermidine trihydrochloride and spermine tetrahydrochloride from Sigma Chemical Co. (38). Petri dishes were purchased from Falcon Plastics (39).

The CF fibroblast strains used in this study were established from skin biopsies of patients with clinically proven cystic fibrosis. These strains were numbered 6, 36, and 129. Normal or control cell strains 16, 18, and 85 were obtained from unaffected individuals who, as far as could be determined by history, were not carriers of CF or other inherited diseases. These strains matched the CF strains in terms of the age of donor and passage number (less than five). The details of cell storage and routine culture, monitoring for mycoplasma, and reagent preparation have been previously described (29). Subconfluent cultures were trypsinized and $2 \times 10^{4}$ cells, suspended in $2 \mathrm{ml} \mathrm{F}-12$ plus $15 \%$ fetal calf serum, were plated onto a number of P-35 tissue culture dishes. The following day, designated day 0 , the number of cells that attached to the growing surface (per dish) was determined by counting washed, trypsinized cells in a model B Coulter counter. On this day and the subsequent 2 days, designated days $I$ and 2 , the cells were re-fed with either regular media or media containing specified amounts of polyamines (see figure legends). The inhibitory effect of the polyamines on the proliferation of control and cystic fibrosis cells was determined by daily counting of duplicate dishes over a period of 3 days.

Percentage of proliferation was determined by dividing the number of cells grown at an experimental concentration by the number of cells in the control dish of that cell strain on that day. These values were plotted on log paper and the average concentration of a polyamine causing a $50 \%$ inhibition of proliferation $\left(\mathrm{ID}_{\mathrm{0} 0}\right)$ was obtained at the intersection of this line with that of $50 \%$ proliferation. The fractional change in cell number was determined by dividing the number of cells found for a particular strain on day 1,2 , or 3 by that strain's own day 0 cell count. This ratio was computed for each of five polyamine concentrations on each of 3 days. Means and standard deviations of these values for each of three normal and three CF cell strains were tabulated. For each concentration of spermidine or spermine, the percentage of the control count on day 3 was also computed.

\section{RESULTS}

Figure $1 A$ is a typical growth curve showing the effect of different concentrations of spermidine upon a normal cell strain. Figure $1 B$ shows the effect of spermidine upon a typical $C F$ cell strain. Figure 1, $C$ and $D$, shows the effect of spermine at the same concentrations on representative normal and $C F$ cell strains. The $\mathrm{CF}$ and normal cells do not differ from each other in growth response to spermidine or spermine over a wide range of concentrations. Linearity of the control growth curves indicates logarithmic growth of cells. Spermidine concentrations of $10^{-4} \mathrm{M}$ invariably actively kill fibroblasts, whereas concentrations of $10^{-5}$ $\mathrm{M}$ almost completely prevent proliferation. Spermidine at $10^{-6} \mathrm{M}$ or $5 \times 10^{-6} \mathrm{M}$ allows some cellular proliferation, but inhibits growth compared with the control (no spermidine added). Spermidine at $10^{-7}$ shows a slight enhancement of growth which is consistent but not statistically significant. Spermine at concentrations of $10^{-4}$ or $10^{-5}$ invariably kills cells, whereas concentrations of $5 \times 10^{-6} \mathrm{M}, 10^{-6} \mathrm{M}$, and $10^{-7} \mathrm{M}$ inhibit proliferation to varying extents. Spermine at $10^{-7} \mathrm{M}$ shows no consistent enhancement of growth over the control, as seen with spermidine.

Table 1 shows the fractional change in cell numbers for each of the three normal and three CF cell strains at the different spermidine concentrations on days 1,2 , and 3 of the experiment. Table 2 provides similar information for spermine. For both spermidine and spermine, none of the average fractional changes for normal cell strains differs significantly $(P>0.05)$ from the average fractional changes for $C F$ cell strains. This is true of all five concentrations on all 3 days.

In Figure $2 A$, the means and standard deviations of the percentages of the day 3 control cell count for three CF and for three normal cell strains are plotted against the $\log$ of the concentration of spermidine. Figure $2 B$ shows a similar graph for spermine. Plots for days $I$ and 2 resemble those for day 3 , only with less negative slopes. Figure $2, A$ and $B$, graphically presents the similarity with which $C F$ and normal cells are affected by polyamines.

Table 3 gives the $I_{60}$ values for spermidine after 1,2 , and 3 days of exposure. Results are presented as means \pm standard deviations for three strains each of normal and CF cells. Table 4 shows similar results for spermine. Note that the $I_{50}$ values for spermidine and spermine decrease with the duration of polyamine feeding. Again, CF cells do not differ significantly $(P>$ 0.05 ) from normal cells in average $I_{s o}$ values for spermidine or spermine.

If the $I_{B 0}$ values for each of the normal and $C F$ cell strains are combined and averaged, then each day's average $\mathrm{ID}_{50}$ for spermidine can be compared with that day's average ${ }_{1 D_{50}}$ for spermine. If this is done, spermine's average $I_{50}$ is found to be significantly less $(P<0.01)$ than spermidine's for each of the 3 days, indicating that spermine is more toxic to both types of cells than spermidine. The average ratio of the $I_{50}$ for spermidine to the $I_{D_{0}}$ for spermine is 2.8 .

\section{DISCUSSION}

The inhibition of cell growth by polyamines has been studied in different cells under different conditions. Alarcon et al. (4) found spermine to have an $\mathrm{ID}_{b 0}$ of approximately $3 \times 10^{-6} \mathrm{M}$ for mammalian cell lines (Ehrlich's ascites, S-91, P-1534, and L-1210) in media supplemented with $5 \%$ whole calf serum. Higgins et al. (17) studied the effect of spermine on plating efficiency in K B cells. Using $10 \%$ fetal bovine serum in medium 199, she found that 9.0 $\mu \mathrm{g} / \mathrm{ml}\left(2.6 \times 10^{-6} \mathrm{M}\right)$ spermine inhibits plating efficiency by $50 \%$. Alarcon (1) studied S-180 mammalian cells in culture media 

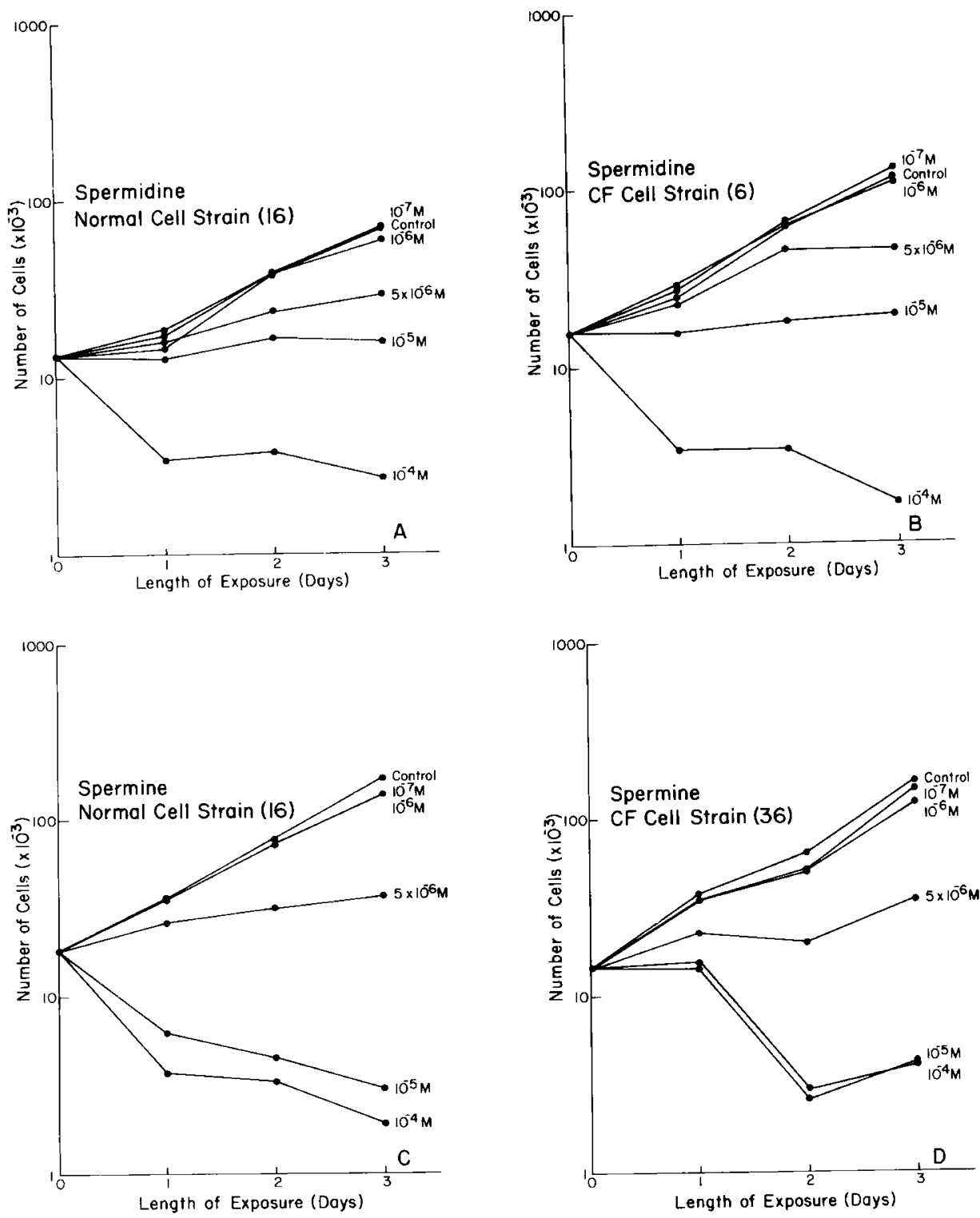

Fig. 1. $A-D$ show the $\log$ of the number of cells plotted against length of exposure to spermidine or spermine for typical cell strains derived from normal or from cystic fibrosis patients. The log scale of the ordinate covers $10^{3}-10^{6}$ cells. The control is with no polyamine added. Each line indicates a single spermidine or spermine concentration. Each graph is for a single polyamine and a single cell strain. See text for further details.

Table 1. Fractional changes in cell number of normal $(N)$ and cystic fibrosis $(C F)$ fibroblasts during 3 days in culture with various concentrations of spermidine ${ }^{1}$

\begin{tabular}{|c|c|c|c|c|c|c|}
\hline & Control & $10^{-7} \mathrm{M}$ & $10^{-6} \mathrm{M}$ & $5 \times 10^{-6} \mathrm{M}$ & $10^{-5} \mathrm{M}$ & $10^{-4} \mathrm{M}$ \\
\hline \multicolumn{7}{|l|}{ Day I } \\
\hline$N$ & $1.88 \pm 0.70$ & $2.10 \pm 0.80$ & $2.06 \pm 0.88$ & $1.85 \pm 0.66$ & $1.45 \pm 0.51$ & $0.30 \pm 0.04$ \\
\hline $\mathrm{CF}$ & $1.97 \pm 0.42$ & $2.24 \pm 0.46$ & $2.21 \pm 0.37$ & $1.91 \pm 0.43$ & $1.41 \pm 0.51$ & $0.31 \pm 0.12$ \\
\hline \multicolumn{7}{|l|}{ Day 2} \\
\hline $\mathrm{N}$ & $4.13 \pm 2.06$ & $4.58 \pm 3.03$ & $4.42 \pm 2.87$ & $2.75 \pm 1.63$ & $1.61 \pm 0.65$ & $0.25 \pm 0.03$ \\
\hline $\mathrm{CF}$ & $4.09 \pm 1.24$ & $3.82 \pm 0.97$ & $3.76 \pm 1.07$ & $2.57 \pm 0.67$ & $1.30 \pm 0.23$ & $0.20 \pm 0.04$ \\
\hline \multicolumn{7}{|l|}{ Day 3} \\
\hline $\mathrm{N}$ & $9.80 \pm 7.40$ & $10.03 \pm 7.27$ & $9.08 \pm 6.68$ & $4.23 \pm 2.68$ & $1.76 \pm 0.53$ & $0.27 \pm 0.07$ \\
\hline $\mathrm{CF}$ & $8.79 \pm 4.04$ & $9.34 \pm 3.62$ & $8.25 \pm 3.32$ & $3.89 \pm 1.52$ & $1.75 \pm 0.52$ & $0.22 \pm 0.12$ \\
\hline
\end{tabular}

${ }^{1}$ See text for details of the experiment. The values are the average of three determinations \pm standard deviation of the mean.

supplemented with $10 \%$ horse serum and $1 \%$ calf serum and found the $\mathrm{ID}_{\mathrm{s0}}$ for spermine to be $1.4-1.5 \times 10^{-5} \mathrm{M}$ and for spermidine to be $2.8-3.1 \times 10^{-5} \mathrm{M}$. The present study, using F-12 medium and $15 \%$ fetal calf serum. shows spermidine's average $I_{50}$ values for three normal and three CF cell strains on day 3 to be $4.4 \pm 1.2$ $\times 10^{-6} \mathrm{M}$ and $6.2 \pm 2.1 \times 10^{-6} \mathrm{M}$, respectively. The $\mathrm{ID}_{\mathrm{b0}}$ values for spermine are $2.0 \pm 0.5 \times 10^{-6} \mathrm{M}$ (normal) and $2.2 \pm 0.1 \times$ $10^{-6} \mathrm{M}(\mathrm{CF})$. 
Table 2. Fractional changes in cell number of normal $(N)$ and cystic fibrosis $(C F)$ fibroblasts during 3 days in culture with various concentrations of spermine ${ }^{1}$

\begin{tabular}{|c|c|c|c|c|c|c|}
\hline & Control & $10^{-7} \mathrm{M}$ & $10^{-6} \mathrm{M}$ & $5 \times 10^{-6} \mathrm{M}$ & $10^{-5} \mathrm{M}$ & $10^{-4} \mathrm{M}$ \\
\hline \multicolumn{7}{|l|}{ Day 1} \\
\hline $\mathbf{N}$ & $2.15 \pm 0.27$ & $2.41 \pm 0.57$ & $2.18 \pm 0.26$ & $1.56 \pm 0.16$ & $0.50 \pm 0.31$ & $0.16 \pm 0.05$ \\
\hline $\mathrm{CF}$ & $1.94 \pm 0.59$ & $1.85 \pm 0.49$ & $1.92 \pm 0.42$ & $1.34 \pm 0.34$ & $0.61 \pm 0.32$ & $0.71 \pm 0.32$ \\
\hline \multicolumn{7}{|l|}{ Day 2} \\
\hline$N$ & $5.12 \pm 0.75$ & $5.23 \pm 1.16$ & $4.43 \pm 0.68$ & $2.00 \pm 0.29$ & $0.30 \pm 0.09$ & $0.18 \pm 0.04$ \\
\hline $\mathrm{CF}$ & $3.87 \pm 0.75$ & $3.74 \pm 0.62$ & $3.33 \pm 0.48$ & $1.44 \pm 0.21$ & $0.17 \pm 0.02$ & $0.16 \pm 0.06$ \\
\hline \multicolumn{7}{|l|}{ Day 3} \\
\hline $\mathbf{N}$ & $12.00 \pm 4.72$ & $11.92 \pm 4.27$ & $8.63 \pm 2.40$ & $2.03 \pm 0.58$ & $0.22 \pm 0.07$ & $0.13 \pm 0.05$ \\
\hline $\mathrm{CF}$ & $9.00 \pm 2.11$ & $8.92 \pm 2.03$ & $7.03 \pm 1.48$ & $1.96 \pm 0.53$ & $0.29 \pm 0.12$ & $0.25 \pm 0.11$ \\
\hline
\end{tabular}

${ }^{1}$ See text for details of experiment. The values are the average of three determinations \pm standard deviation of the mean.

Table 3. Spermidine $I D_{50}[M]^{1}$
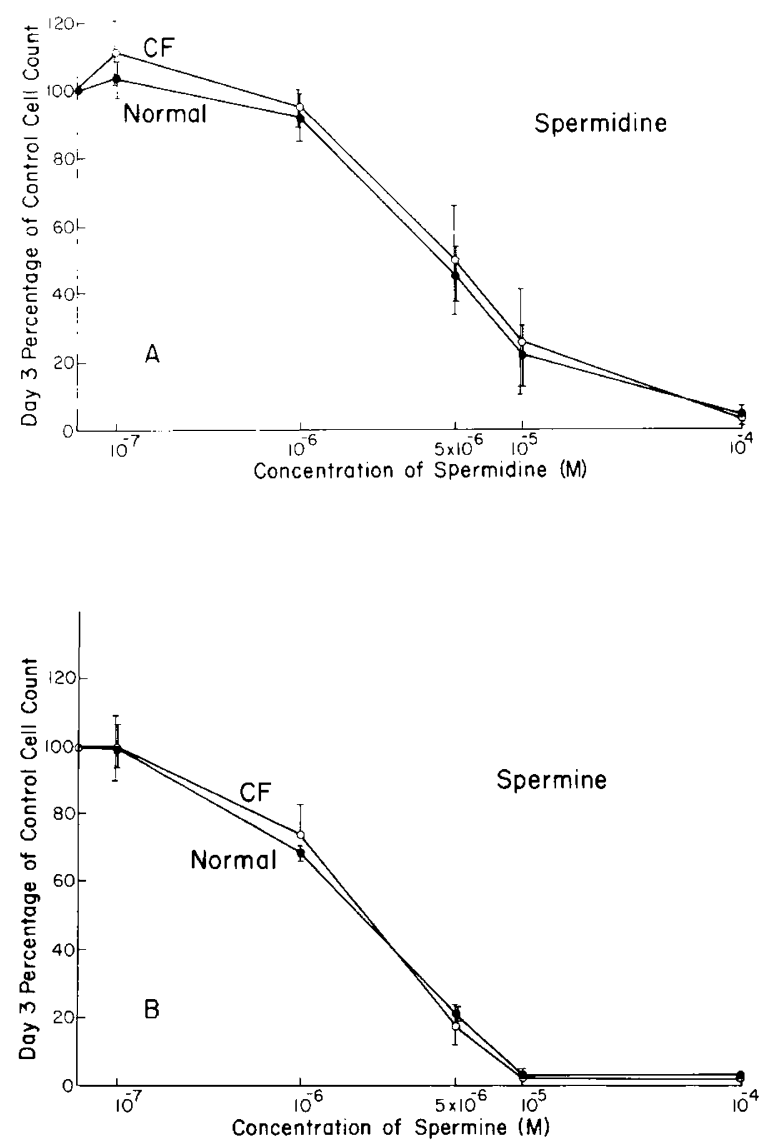

Fig. 2. Shows the percentage of the control (no added polyamine) number of cells on day 3 plotted against the $\log$ of the concentration of spermidine $(A)$ and spermine $(B)$. Each point and vertical bar give the mean and standard deviation for three normal $(\bigcirc)$ or three cystic fibrosis $(C F)$ (O) cell strains.

This paper studies the toxicity of spermidine and spermine to human fibroblasts as gauged by the gross parameter of cell number (see figures and tables). We did not attempt to correlate exogenous with endogenous polyamine concentration, or with specific morphologic, biochemical, or functional impairments. Toxicity to stationary cultures was not investigated. Although findings obtained with the use of only one medium $(\mathrm{F}-12)$ and one concentration of a single serum ( $15 \%$ fetal calf serum) are presented here, the effect of spermidine on normal and CF fibroblasts was found to be similar for F-12 with $5 \%$ calf serum and $10 \%$ fetal calf serum under an altered feeding regimen (8). Spermidine was also found to be

\begin{tabular}{crc}
\hline Day & Normal, [M] & CF, [M] \\
\hline 1 & $29.7 \times 10^{-6} \pm 8.6$ & $20.3 \times 10^{-6} \pm 8.7$ \\
2 & $7.6 \times 10^{-6} \pm 0.4$ & $9.1 \times 10^{-6} \pm 4.3$ \\
3 & $4.4 \times 10^{-6} \pm 1.2$ & $6.2 \times 10^{-6} \pm 2.1$ \\
\hline
\end{tabular}

${ }^{1}$ See text for details of experiment. The values are the average of three determinations \pm standard deviation of the mean.

Table 4. Spermine $I D_{50}[M]^{1}$

\begin{tabular}{ccc}
\hline Day & Normal, $[\mathrm{M}]$ & $\mathrm{CF},[\mathrm{M}]$ \\
\hline 1 & $6.9 \times 10^{-6} \pm 0.4$ & $7.1 \times 10^{-6} \pm 0.2$ \\
2 & $3.5 \times 10^{-6} \pm 0.3$ & $3.4 \times 10^{-6} \pm 0.7$ \\
3 & $2.0 \times 10^{-6} \pm 0.5$ & $2.2 \times 10^{-6} \pm 0.1$ \\
\hline
\end{tabular}

${ }^{1}$ See text for details of experiment. The values are the average of three determinations \pm standard deviation of the mean.

less inhibitory for fibroblasts' growth when Eagle's minimum essential medium (MEM) and 15\% calf serum or fetal calf serum was used than when F-12 media was used (8). This may reflect the fact that MEM contains no putrescine, whereas F-12 medium contains $10^{-6} \mathrm{M}$ putrescine, although the extent of conversion of putrescine to spermidine by fetal calf serum is unknown. Alternatively, other differences between MEM and F-12 media might account for the differential effect upon spermidine's toxicity to fibroblasts.

The reason for the inhibitory effect of polyamines on cellular proliferation remains unclear. Past investigations emphasize the requirement for a diamine oxidase in order for the toxic effects of polyamines to be observed $(4,18)$. They suggest that oxidized spermidine $\left(\mathrm{H}_{3} \mathrm{~N}-\left(\mathrm{CH}_{2}\right)_{4} \mathrm{NHCH}_{2}-\mathrm{CH}_{2} \quad \mathrm{C}>\mathrm{O}\right)$ and oxidized spermine $\left(\begin{array}{l}\mathrm{O}_{-} \\ \mathrm{H}^{\prime}\end{array}\right.$ provide reactive aldehydes toxic to cell growth (6). Calf serum contains a diamine oxidase which forms aldehydes from the terminal $-\mathrm{CH}_{2} \mathrm{CH}_{2} \mathrm{CH}_{2} \mathrm{NH}_{3}$ groups of polyamines $(7,34,35)$. Investigations to determine whether an inhibitor of this diamine oxidase can relieve polyamine toxicity to growth are being conducted in this laboratory. Alarcon (2) has further suggested that acrolein $\left(\mathrm{CH}_{2}=\mathrm{CH}-\mathrm{C}=\mathrm{H}\right)$ is formed as a nonenzymatic breakdown product of oxidized spermine or spermidine. He identified acrolein in fetal calf serum incubated with spermidine or spermine at $37^{\circ}$ for $6 \mathrm{hr}(2)$. Kimes and Morris (21) supported the contention that 
acrolein is a breakdown product of oxidized polyamines, and acrolein has been put forth as a universal cell growth inhibitor (3). Whether the oxidized polyamine itself or its alleged product, acrolein, is the toxic substance, stoichiometry predicts that spermine will produce twice the inhibition of growth that spermidine does. Indeed, this effect obtains in our study (Tables 3 and 4).

Although putrescine apparently promotes growth of cultured fibroblasts and other mammalian cells $(14,15,27,28)$, its metabolic products, spermidine and spermine, inhibit fibroblast proliferation at concentrations greater than $10^{-6} \mathrm{M}$. This suggests that there is a concentration of polyamines optimal for proliferation and that polyamines are both positive and negative regulators of growth as they approach or exceed that optimal concentration.

In these studies we found no difference in the effects of polyamines upon normal and CF fibroblasts. Recent reports of abnormal whole blood polyamine levels in patients with cystic fibrosis $(5,10,23,25,30)$ have indicated that polyamines are increased in blood cells and not in serum. Since our studies did not include an investigation of the entrance of polyamines into cells of any kind, no comparison can be drawn between our in vitro experiments and in vivo conditions. We can say, however, that cultured fibroblasts from patients with cystic fibrosis do not differ from those of normal patients in their susceptibility to exogenous polyamines' toxicity.

\section{SUMMARY}

Spermidine and spermine at concentrations greater than $10^{-6} \mathrm{M}$ were found to inhibit proliferation of human fibroblasts in vitro. No difference was observed between normal cells and those derived from patients with cystic fibrosis.

\section{REFERENCES AND NOTES}

1. Alarcon, R. A.: Isolation of acrolein from incubation mixtures of spermine with calf serum and its effects on mammalian cells. Arch. Biochem. Biophys., 106 : $240(1964)$

2. Alarcon, R. A.: Acrolein. IV. Evidence for the formation of the cytotoxic aldehyde acrolein from enzymatically oxidized spermine or spermidine. Arch. Biochem. Biophys., 137: 365 (1970).

3. Alarcon, R. A.: Acrolein, a component of a universal cell-growth regulatory system: A theory. J. Theor. Biol., 37: 159 (1972).

4. Alarcon, R. A., Foley, G. E., and Modest, E. J.: Effects of spermine on mammalian cells. Arch. Biochem. Biophys., 94: 540 (1961)

5. Arvanitakis, S. N., Mangos, J. A., McSherry, N. R., Rennert, O. M.. and Lapointe, D.: Role of polyamines in cystic fibrosis (CF). Pediat. Res., 7 : 336/108 (1973)

6. Bachrach, U., Abzug, S., and Bekierkunst, A.: Cytotoxic effect of oxidized spermine on Ehrlich ascites cells. Biochim. Biophys. Acta, 134: 174 (1967)

7. Blaschko, H., and Hawes, R.: Observations on spermine oxidase of mammalia plasma. J. Physiol., 145: 124 (1959).

8. Changus, J. E., and Quissell, D. O.: Personal communication.

9. Cohen, S. S.: Introduction to Polyamines, pp. 1-179 (Prentice Hall, Englewood Cliffs, N. J., 1971)

10. Cohen, L. F., Farrell, P. M., Willison, J. W., and Lundgren, D. W.: Localization of spermidine (Spd) and spermine $(\mathrm{Spm})$ in blood of cystic fibrosis $(\mathrm{CF})$ and control subjects. Pediat. Res., 9: 334/312 (1975)

11. Dykstra, W. G., Jr., and Herbst, E. J.: Spermidine in regenerating liver: Relation to rapid synthesis of ribonucleic acid. Science, 149: 428 (1965).

12. Gibson, L. E., and Cooke, R. E.: A test for concentration of electrolytes in swea in cystic fibrosis of the pancreas utilizing pilocarpine by iontophoresis. Pediatrics, 23: 545 (1959).

13. Goldstein, J.: The effect of spermine on the accumulation of nucleic acids and protein in mammalian cells. Exp. Cell Res., 37: 494 (1965).

4. Ham, R. G.: Putrescine and related amines as growth factors for a mammalian cell line. Biochem. Biophys. Res. Commun., 14: 34 (1964).

15. Ham, R. G.: Nutritional requirements of primary cultures: A neglected problem of modern biology. In Vitro, 10: 119 (1974).

16. Herbst, E J., and Bachrach, U. (Eds.): Metabolism and biological functions of polyamines. Ann. N. Y. Acad. Sci., 171: 691 (1970)

17. Higgins, M. L., Tillman, M. C., Rupp, J. P., and Leach, F. R.: The effect of polyamines on cell culture cells. J. Cell Physiol., 74: 149 (1969).

18. Hirsch, J. G.: Spermine oxidase: An amine oxidase with specificity for spermine and spermidine. J. Exp. Med. 97: 345 (1953).

19. Hirsch, J. G., and Dubos, R. J.: The effect of spermine on tubercle bacilli. J. Exp. Med., 95: 191 (1952)

20. Janne, J.: Studies on the biosynthetic pathway of polyamines in rat liver. Acta Physiol. Scand. Suppl., 300: 1 (1967).

21. Kimes, B. W., and Morris, D. R.: Preparation and stability of oxidized polyamines. Biochim. Biophys. Acta, 228: 223 (1971).

22. Lobeck, C. C.: Cystic fibrosis. In: J. B. Stanbury, J. B. Wyngaarden, and D. S Fredrickson: Metabolic Basis of Inherited Disease, Ed. 3, p. 1616 (Academic Press, New York, 1972).

23. Lundgren, D. W., and Farrell, P. M.: Alteration in blood polyamines in cystic fibrosis patients. In: Cystic Fibrosis Club Abstracts, p. 2, April 30, 1974 (Cystic Fibrosis Foundation, Atlanta, 1974)

24. Mager, J.: The stabilizing effect of spermine and related polyamines on bacteria protoplasts. Biochim. Biophys. Acta, 36: 529 (1959)

25. Munro, G. F., Lederman, M., and Miller, R. A.: Polyamines in blood and fibroblasts from cystic fibrosis patients. In: Cystic Fibrosis Club Abstracts, p. 7, April 15, 1975, Denver, Colorado (Cystic Fibrosis Foundation, Atlanta, Ga., 1975).

26. Otsuka, H.: The toxic effect of spermidine on normal and transformed cells. J. Cell Sci., 9: 71 (1971).

27. Pohjanpelto, P.: Relationship between putrescine and the proliferation of human fibroblasts in vitro. Exp. Cell Res., 80: 137 (1973).

28. Pohjanpelto, P., and Raina, A.: Identification of a growth factor produced by human fibroblasts in vitro as putrescine. Nature New Biol., 235: 247 (1972).

29. Quissell, D. O., and Changus, J. E.: Solubilization and gel electrophoresis of human fibroblast plasma membrane proteins in a nondetergent system. (Submitted to Annals of Biochemistry.)

30. Rennert, O., Frias, J., and Lapointe, D.: Methylation of RNA and polyamine metabolism in cystic fibrosis. In: J. A. Mangos and R. C. Talamo: Fundamental Problems of Cystic Fibrosis and Related Diseases, p. 41 (Intercontinental Medical Book Corporation, New York, 1973)

31. Rozansky, R., Bachrach, U., and Grossowicz, N.: Studies on the antibacteria action of spermine. J. Gen. Microbiol., 10: 11 (1954)

32. Russell, D. H.: Polyamines in growth-Normal and neoplastic. In: D. Russell: Polyamines in Normal and Neoplastic Growth (Raven Press Books, Ltd., New York, 1973)

33. Russell, D. H., and Levy, C. C.: Polyamine accumulation and biosynthesis in a mouse L1210 leukemia. Cancer Res., 31: 248 (1971).

34. Tabor, C. W. Tabor, H., and Bachrach, U.: Identification of the aminoaldehyde produced by the oxidation of spermine and spermidine with purified plasma amine oxidase. J. Biol. Chem., 239: 2194 (1964).

35. Tabor, C. W., Tabor, H., and Rosenthal, S. M.: Purification of amine oxidase from beef plasma. J. Biol. Chem., 208: 645 (1954)

36. Tabor, $H$., and Tabor, C. W.: Spermidine, spermine and related amines. Pharmacol. Rev., 16: 245 (1964)

37. Grand Island, N. Y

38. St. Louis, Mo.

39. Oxnard, Calif.

40. The authors thank Mary Sukup, Ann Vale, and Naomi Williams for their excellent technical assistance.

41. Biopsies were obtained from patients with their informed consent. The form used and signed by each patient was approved by the Humap Subject Experimentation Committee of the University of Wisconsin and is available on request.

42. This work was supported in part by a grant from the National Institute of Arthritis and Metabolism (AM-13380). Dr. J. E. Changus is a Trainee in Oncology of the National Cancer Institute (T01 CA 5002).

43. Requests for reprints should be sent to: H. C. Pitot, M.D., McArdle Laboratories, The Center for Health Sciences, University of Wisconsin, Madison, Wis. 53706 (USA)

44. Accepted for publication December 1, 1975. 